\title{
Trace element intake via soil ingestion in pronghorns and in
} black-tailed jackrabbits

\author{
W. JOHN ARTHUR, III, AND ROBERT J. GATES
}

\section{Abstract}

Soll ingestion ratios were estimated for 2 primary herbivore species utilizing a sagebrush ecosystem in southeastern Idaho to determine the relative importance of soil and vegetation pathways in trace element ingestion and to make predictions of the importance of these pathways for toxic and radioactive elemental intake. The mean ( $\bar{x}$ and $95 \% \mathrm{CI})$ soll intake rates for pronghorns (Antilocapra americana) and black-tailed jackrabbits (Lepus calffornicus) were 48.7 (45.0-52.7) and $9.7(9.0-10.6) \mathrm{g} / \mathrm{day}$, respectively, with sexsonal peaks occurring in spring (March-May) and in fall (August-October). We did not determine whether soil intake resulted from direct soil ingestion or soil attachment to ingested forage. Soil comprised $5.4 \%$ and $6.3 \%$, respectively, of the pronghorn and jackrabbit total dry matter intake. Relating trace element concentrations in soil and vegetation to the daily soll and forage intake rates permitted an estimate of the importance of these 2 ingestion pathways. For both pronghom and jackrabbits, the estimated percentage of elemental intake attributable to soil was 75\% (Na, Fe, V, and F) and 10-50\% (Mn, Cr, Mg, Ni, $\mathrm{K}$ and $\mathrm{Zn}$ ).

Key Words: Antilocapra americana, black-tailed jackrabbit, environmental contaminants, Lepus calfornicus, nutrition, pronghorn, soil ingestion, trace elements

Weeks and Kirkpatrick (1976) and Salter and Pluth (1980) documented seasonal variation in soil or grit intake by white-tailed deer (Odocoileus virginianus), fox squirrels (Sciurus niger), woodchucks (Marmota monax), and feral horses. These studies related soil or grit ingestion to increased demand for sodium, primarily

\footnotetext{
Authors are former radioecologist, U.S. Dept. Energy and graduate research assistant, Montana State Univ., respectively. The senior author is currently deputy manager, Uranium Mill Tailings Remedial Action Project, U.S. Dept. of Energy, Albuquerque Oper. Off., P.O. Box 5400, Albuquerque, NM 87115. The second author is currently wildlife research assistant, Cooperative Wildl. Res. Lab., Southern Illinois Univ. at Carbondale, Carbondale, Ill. 62901.

Contribution of the Idaho Nat. Eng. Lab. Radioecology and Ecology Program.

Funds for this research were provided by the Off. Health and Environ. Res., U.S. Dep. Energy. This article was published as a J. Ser.000, Mont. Agr. Exp. Sta. Authors thank B.W. Mortenson, J.C. Grant, J.E. Canfield, M. C. Ogle, and J. Gingerich for the manuscript.

Manuscript accepted 29 October 1987.
}

during the spring. Few previous studies have dealt with the quantity of soil ingested by wildlife (Skipworth 1974, Arthur and Alldredge 1979), and only minimal information exists on the importance of soil in trace element intake.

We initiated research in December 1980 on the $8,310-\mathrm{km}^{2}$ Idaho National Engineering Laboratory (INEL) in southeastern Idaho to determine the mass of soil ingested seasonally by pronghorns and black-tailed jackrabbits. In conjunction with research on pronghorn and jackrabbit food habits at the study site, vegetation dietary components and soil samples were analyzed for trace elements. Comparisons of the quantities of trace elements ingested via soil and vegetation intake were made based on the concentrations of these elements in soils and vegetation. This paper presents an indirect method to determine the masses of soil ingested by pronghorn and black-tailed jackrabbits in southeastern Idaho and evaluates the potential importance of this intake mechanism for ingestion of trace elements.

\section{Study Area}

The study area, elevation $1,460-1,650 \mathrm{~m}$, encompassed $300 \mathrm{~km}^{2}$ of the west central portion of the INEL, $16 \mathrm{~km}$ south of Howe, Butte County, Idaho. Surface soils along the west boundary of the study area are slightly calcareous loams derived from loess and limestone alluvium deposited from the Lost River Range. The remainder of the study area (approximately $90 \%$ ) is a thin loesscovered basalt plain. Surface soils in this area are silt loam and rocky silt loam and are noncalcareous to slightly calcareous. Vegetation associated with alluvial soils is dominated by big sagebrush (Artemisia tridentata), winterfat (Ceratoides lanata), and green rabbitbrush (Chrysothamnus viscidiflous). Two vegetation types occurred on the remainder of the study area, a big sagebrush-green rabbitbrush-bottlebrush squirreltail (Elymus elymoides) type and a big sagebrush-bluebunch wheatgrass (Pseudoroegnaria spicatum)green rabbitbrush type (McBride et al. 1978). Giant wildrye (Leymus cinereus) occurred in isolated stands throughout the study area.

The estimated density of jackrabbits on the northwest section of 
the study area was $2.9 /$ ha throughout most of the study (R.J. Gates, unpubl. data), and the population was thought to be a cyclic peak in 1981 (Anderson and Johnson 1983, Stoddart 1983). Pronghorns used the study area primarily during the winter and spring but were observed there throughout the study period. During the winter and early spring of $1981,200-300$ pronghorns were observed on the southwest section of the study area.

\section{Methods}

We estimated the quantity of soil ingested by determining titanium concentrations in soil, vegetation, and feces. The experimental approach has been described previously by Healy (1968) and Mayland et al. (1975), and is based on the premise that titanium is relatively abundant in soil $(1,000$ to $3,000 \mathrm{ppm})$ and is not metabolized by vegetation or animal tissues (usually $<1 \mathrm{ppm}$ ). Low concentrations of titanium in animal tissues and vegetation supported this contention. Because titanium found in fecal material results from soil intake (Mayland et al. 1975), concentrations of titanium in feces and soil provide an estimate of the animal's soil intake rates.

Twenty surface $(0-5 \mathrm{~cm})$ soil samples and 28 vegetation (big sagebrush leaves and grass composites) samples were collected in May 1982. Between December 1980 and November 1981, 10-19 pronghorn pellet groups and 7-14 jackrabbit fecal samples were collected monthly. Only recently deposited feces were collected and samples were collected opportunistically within the study area. Pronghorn samples were collected by observing animals in the study area and searching utilized areas for fresh fecal samples; whereas jackrabbit samples were collected throughout the entire area. Metacarpel bone, muscle, liver, and kidney samples were obtained from 10 jackrabbits collected from the study area in November 1980 and April 1981 and from 7 road-killed pronghorns.

All animal tissue, vegetation, and fecal samples were ultrasonically washed in demineralized water for $>0.5$ hour to remove surface-attached soil particles. Fecal samples also were scrubbed with a brush to facilitate removal of surface soil contamination. A minimum of $20 \%$ of the fecal pellets were viewed microscopically to assure removal of surface-attached soil particles. Samples were oven-dried for 72 hours at $70^{\circ} \mathrm{C}$, screened through a 2-mm mesh screen and sent to a commercial laboratory where they were acid digested (combination of nitric and perchloric acid), and analyzed for titanium by flame atomic absorption (S. Moore, pers. commun.). The lower detection limit for $\mathrm{Ti}$ in soil and animal tissues and in vegetation was $10 \mathrm{ppm}$ and $0.6 \mathrm{ppm}$, respectively. Twenty percent of the samples were analyzed in duplicate to assure consistency in spectrophotometer readings. National Bureau of Standards reference samples were analyzed for quality assurance.

Estimates of the quantity of soil ingested were derived from the following model:

$$
S_{\text {day }}=\frac{\left({ }^{P} \mathrm{Ti} \times{ }^{P} \text { day }\right)-\left({ }^{\mathrm{V}} \mathrm{Ti} \times{ }^{\mathrm{v}_{\text {day }}}\right)}{S_{\mathrm{Ti}}}
$$

where

$8_{\text {day }}=$ soil mass $(g)$ ingested $/$ day,

${ }^{\mathrm{F}_{\mathrm{Ti}}}=$ titanium concentration $(\mu \mathrm{g} / \mathrm{g})$ in feces,

$F_{\text {day }}=$ dry weight $(g)$ feces defocated/day,

$\mathrm{v}_{\mathrm{Ti}}=$ titanium concentration $(\mu \mathrm{g} / \mathrm{g})$ in vegetation,

$v_{\text {day }}=$ dry weight $(g)$ vegetation consumed/day, and

${ }^{\mathrm{s}} \mathrm{Ti}=$ mean titanium concentration $(\mu \mathrm{g} / \mathrm{g})$ in surface soil. We used an average daily forage intake (dry wt) of $145 \mathrm{~g}$ for black-tailed jackrabbits (Arnold and Reynolds 1943) and $850 \mathrm{~g}$ for pronghorns (Severson et al. 1968) to estimate soil ingestion. We assumed dry matter digestibilities of $43 \%$ for diets of jackrabbits (Arnold and Reynolds 1943) and 54\% for pronghorns (Welch et al. 1983). Based on these assumptions, the mean daily defecation rates used in the model were 82 for jackrabbits, $391 \mathrm{~g} /$ day for pronghorns.

Mean soil ingestion rates were calculated for each month. Oneway analysis of variance was used to determine significant differ- ences in soil intake rates among months. A significance level of $P<0.05$ was used for rejection of the null hypothesis. Duncan's new multiple range test (Duncan 1955) was used to separate statistically different means.

Soil and vegetation samples were analyzed for $\mathrm{Ca}, \mathrm{Cr}, \mathrm{Cu}, \mathrm{F}, \mathrm{Fe}$, $\mathrm{K}, \mathrm{Mg}, \mathrm{Mn}, \mathrm{Na}, \mathrm{Ni}, \mathrm{P}, \mathrm{V}$, and $\mathrm{Zn}$ by a conductively coupled argon plasma spectrograph. Minimum detection limits (ppm) for these elements in soil were $\mathrm{Ca}(10), \mathrm{Cr}(0.5), \mathrm{Cu}(1), \mathrm{F}(10), \mathrm{Fe}(20), \mathrm{K}(1)$, $\mathrm{Mg}(20), \mathrm{Mn}(10), \mathrm{Na}(10), \mathrm{Ni}(1), \mathrm{P}(10), \mathrm{V}(1)$, and $\mathrm{Zn}$ (5). Mean concentrations of the 13 elements in soil and vegetation were multiplied by mean daily soil and vegetation intake rates. The percentage of daily intake of each element was compared for soil vs. vegetation consumption for both pronghorns and black-tailed jackrabbits.

\section{Results}

Titanium concentrations in surface $(0-5 \mathrm{~cm})$ soils at the study area ranged from 3,770 to $6,140 \mathrm{ppm}$ with a mean $(\bar{x} \pm \mathrm{SD})$ of 5,280 \pm 715 ppm (Table 1). Because pronghorns were observed over the

Table 1. Titanium concentration (ppm) in soll, vegetation and animal thasue on the Idwho National Engineering Laboratory in southeastern Idaho.

\begin{tabular}{llcl}
\hline \hline Media & $\bar{x}+$ SD & n & Range \\
\hline Soil & S280 \pm 715 & 20 & $3770-6140$ \\
Sagebrush leaves & $24.9 \pm 4.9$ & 18 & $18-33$ \\
Grass Composites & $18.7 \pm 7.8$ & 10 & $10-29$ \\
Pronghorn & & & \\
$\quad$ Muscle & BDL* & 6 & - \\
Liver & BDL & 7 & - \\
Bone & BDL & 7 & - \\
Kidney & BDL & 7 & - \\
Feces & $851.3 \pm 363.8$ & 177 & $150-2200$ \\
Jackrabbit & & & \\
Muscle & $13.5 \pm 20.2^{+}$ & 6 & BDL -43 \\
Liver & $29.5 \pm 31.6$ & 5 & BDL -82 \\
Bone & $21.6 \pm 17.5$ & 6 & BDL -52 \\
Kidney & $15.1 \pm 17.6$ & 6 & BDL -37 \\
Feces & $607.7 \pm 250.4$ & 118 & $200-1630$ \\
\hline
\end{tabular}

*BDL = Below detection limits ( $\leq 0.6 \mathrm{ppm})$

$\mathrm{BDL}=\mathrm{Bel}$
$0.6 \mathrm{ppm}$ used to calculate the mean when the sample value was below detection limit.

entire study area, this mean was used to calculate the pronghorn soil intake rate. However, because we collected all black-tailed jackrabbit feces near the northwest portion of the study area, we used the mean titanium concentration of soils in this area $(4,315 \pm$ $432 \mathrm{ppm}$ ) to determine jackrabbit soil intake rates.

Titanium concentrations in washed vegetation samples collected at the study area ranged from 10 to $29 \mathrm{ppm}$ for grass $(\bar{x} \pm \mathrm{SD}=18.7$ \pm 7.8 ) and $18-33 \mathrm{ppm}$ for sagebrush leaves $(\bar{x} \pm \mathrm{SD}=24.9 \pm 4.9)$. The overall mean concentration of $20 \mathrm{ppm}$ titanium was used for forage $\left(V_{\mathrm{Ti}}\right)$ in the soil ingestion rate model.

Titanium concentrations in all pronghorn muscle, liver, bone, and kidney tissue samples were below the lower detection limit of $0.6 \mathrm{ppm}$, indicating little or no tissue absorption of this element. Some jackrabbit tissues had higher titanium concentrations than the pronghorn tissues (Table 1). The reason for these elevated concentrations was unknown.

Because microscopic examination of washed pronghorn and jackrabbit fecal pellets revealed no surface attachment of soil particles, the reported titanium concentrations for feces were assumed to be from soil in feces and not surface contamination. Titanium concentrations in washed jackrabbit and pronghorn fecal samples ranged from 200 to 1630 and 150 to $2200 \mathrm{ppm}$, respectively (Table 1).

The annual mean $(\bar{x} ; 95 \%$ confidence interval) daily soil intake rate estimated for pronghorn was $48.7(45.0-52.7) \mathrm{g} /$ day. 
Table 2. Mean elemental concentrations (ppm) in surface soil and washed vegetation samples on the Idaho National Engineering Laboratory in southeatern Idaho.

\begin{tabular}{|c|c|c|c|c|c|c|c|c|}
\hline \multirow{2}{*}{\multicolumn{2}{|c|}{ Media }} & \multicolumn{7}{|c|}{ Concentration (ppm) } \\
\hline & & \multirow{2}{*}{ 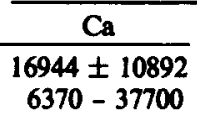 } & \multirow{2}{*}{ 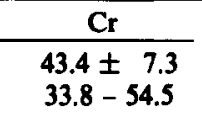 } & $\mathrm{Cu}$ & $\mathrm{Fe}$ & \multirow{2}{*}{ 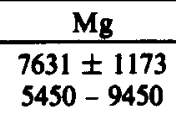 } & $\mathbf{M n}$ & \\
\hline $\begin{array}{l}\text { Soil } \\
(n=12)\end{array}$ & $\begin{array}{l}x \pm S D \\
\text { Range }\end{array}$ & & & $\begin{array}{l}21.5 \pm 4.1 \\
16.2-28.5\end{array}$ & $\begin{array}{l}21033 \pm 2694 \\
17400-26300\end{array}$ & & $\begin{array}{l}402 \pm 79 \\
295-520\end{array}$ & \\
\hline $\begin{array}{l}\text { Grass } \\
(n=6)\end{array}$ & $\begin{array}{l}x \pm \text { SD } \\
\text { Range }\end{array}$ & $\begin{array}{r}15362 \pm 5383 \\
7010-21500\end{array}$ & $\begin{array}{l}7.9 \pm 1.9 \\
6.8-10.7\end{array}$ & $\begin{array}{r}16.7 \pm 14.3 \\
8.9-42.2\end{array}$ & $\begin{array}{lr}530 \pm & 313 \\
333- & 1070\end{array}$ & $\begin{array}{l}2244 \pm 469 \\
1850-3010\end{array}$ & $\begin{array}{cc}56.4 \pm 14.8 \\
40.7-78.0\end{array}$ & \\
\hline \multirow{2}{*}{\multicolumn{2}{|c|}{$\begin{array}{l}\text { Sagebrush Leaves } \\
(\mathrm{n}=11) \quad \mathrm{x} \pm \mathrm{SD} \\
\\
\text { Range }\end{array}$}} & $\begin{array}{l}8554 \pm 1983 \\
6300-12200\end{array}$ & $\begin{array}{r}4.0 \pm 2.5 \\
\mathrm{BDL}^{*}-8.0\end{array}$ & $\begin{array}{l}17.1 \pm 2.1 \\
13.5-20.9\end{array}$ & $\begin{array}{lr}216 \pm & 60 \\
122- & 285\end{array}$ & $\begin{array}{l}1709 \pm 323 \\
1030-2120\end{array}$ & $\begin{array}{lr}35.9 \pm & 6.9 \\
27.6-47.6\end{array}$ & \\
\hline & & \multicolumn{7}{|c|}{ Concentration (ppm) } \\
\hline \multicolumn{2}{|c|}{ Media } & $\mathrm{Ni}$ & $\mathbf{P}$ & $\mathrm{V}$ & $\mathrm{Zn}$ & $\mathbf{F}$ & $\mathrm{Na}^{+}$ & $\mathbf{K}^{+}$ \\
\hline $\begin{array}{l}\text { Soil } \\
(n=12)\end{array}$ & $\begin{array}{l}x \pm S D \\
\text { Range }\end{array}$ & $\begin{array}{l}23.2 \pm 2.7 \\
20.6-29.1\end{array}$ & $\begin{array}{cr}3597 \pm & 738 \\
2780-5530\end{array}$ & $\begin{array}{l}45.9 \pm 6.2 \\
39.3-61.1\end{array}$ & $\begin{array}{c}81.4 \pm 12.3 \\
68.1-102\end{array}$ & $\begin{array}{l}519 \pm 132 \\
300-800\end{array}$ & $\begin{array}{r}10643 \pm 1400 \\
8300-12300\end{array}$ & $\begin{array}{l}22528 \pm 1100 \\
21000-23700\end{array}$ \\
\hline $\begin{array}{l}\text { Grass } \\
(n=6)\end{array}$ & $\begin{array}{l}x \pm S D \\
\text { Range }\end{array}$ & $\begin{array}{r}10.0 \pm 3.7 \\
6.5-12.6\end{array}$ & $\begin{array}{r}10876 \pm 2889 \\
8160-14000\end{array}$ & $\begin{array}{r}0.2 \pm 0.5 \\
\text { BDL }-1.2\end{array}$ & $\begin{array}{l}41.4 \pm 18.3 \\
22.9-69.4\end{array}$ & $\begin{array}{l}30.3 \pm 9.6 \\
14.0-45.0\end{array}$ & $\begin{array}{c}54 \pm 52 \\
\text { BLD - } 176\end{array}$ & $\begin{array}{l}7960 \pm 1170 \\
5900-10700\end{array}$ \\
\hline $\begin{array}{l}\text { Sagebrus } \\
(\mathrm{n}=11)\end{array}$ & $\begin{array}{l}\text { aves } \\
x \pm S D \\
\text { Range }\end{array}$ & $\begin{array}{l}6.7 \pm 6.2 \\
2.5-21.6\end{array}$ & $\begin{array}{l}7777 \pm 2011 \\
3270-10100\end{array}$ & $\underline{\text { BDL }}$ & $\begin{array}{l}29.2 \pm 8.8 \\
18.7-51.4\end{array}$ & $\begin{array}{c}16.9 \pm 11.6 \\
2.0-38.9\end{array}$ & $\begin{array}{r}74 \pm 84 \\
\text { BLD - 461 }\end{array}$ & $\begin{array}{l}15900 \pm 1100 \\
13500-17700\end{array}$ \\
\hline
\end{tabular}

*BLD = Below minimum detection limits for this element.

$n=7,24$ and 32 for soil, grass, and sagebrush, respectively for the elements Na and $K$.

Pronghorn soil intake rates differed significantly $(P<0.001)$ between months, ranging from $21.5 \mathrm{~g} /$ day in June to $84.0 \mathrm{~g} /$ day in March (Fig. 1). Monthly soil intake rates were highest $(P<0.05)$ during March-May, and August-October.

The annual mean $(\bar{x} ; 95 \%$ confidence interval) daily soil intake rate estimated for black-tailed jackrabbits was $9.7(9.0-10.6) \mathrm{g} /$ day. Jackrabbit soil intake rates also varied significantly $(P<0.001)$ between months. The highest soil intake rate was observed in December, with significant $(P \leq 0.05)$ peaks also occurring in March-May and in September and October (Fig. 1).

\section{Elemental Intake Due to Soil Ingestion}

Mean concentrations of $\mathrm{Ca}, \mathrm{Cr}, \mathrm{Cu}, \mathrm{F}, \mathrm{Fe}, \mathrm{K}, \mathrm{Mg}, \mathrm{Mn}, \mathrm{Na}, \mathrm{Ni}$, $P, V$, and $\mathrm{Zn}$ in soils and vegetation at the study area are presented in Table 2. Multiplying the forage and mean annual soil intake

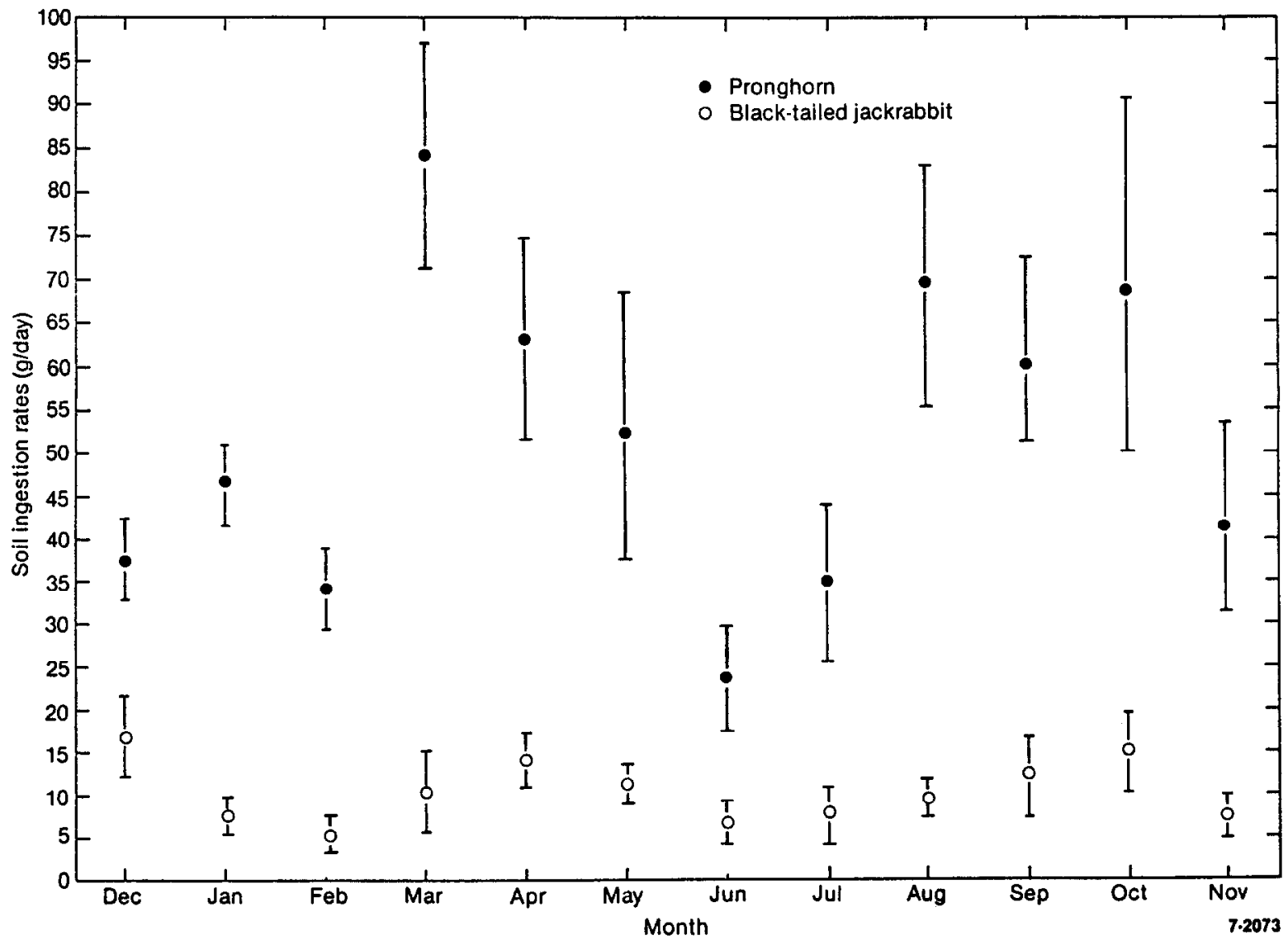

Fig. 1. Daily soil ingestion rates $(\bar{x}, 95 \%$ CI) for black-tailed jackrabbits and pronghorns in southeastern Idaho during December 1980 through November 1981. 
rates of 85 and $48.7 \mathrm{~g} /$ day (pronghorn) and 145 and $9.7 \mathrm{~g} /$ day (jackrabbit) by the mean concentration of elements in each medium provided an estimate of the percentage of the daily intake of elements resulting from soil versus forage intake (Fig. 2). Due to high occurrence of shrubs in pronghorn and jackrabbit diets on the study area (Gates, unpublished data), concentrations of elements in sagebrush leaves (Table 2) were used for the forage category.
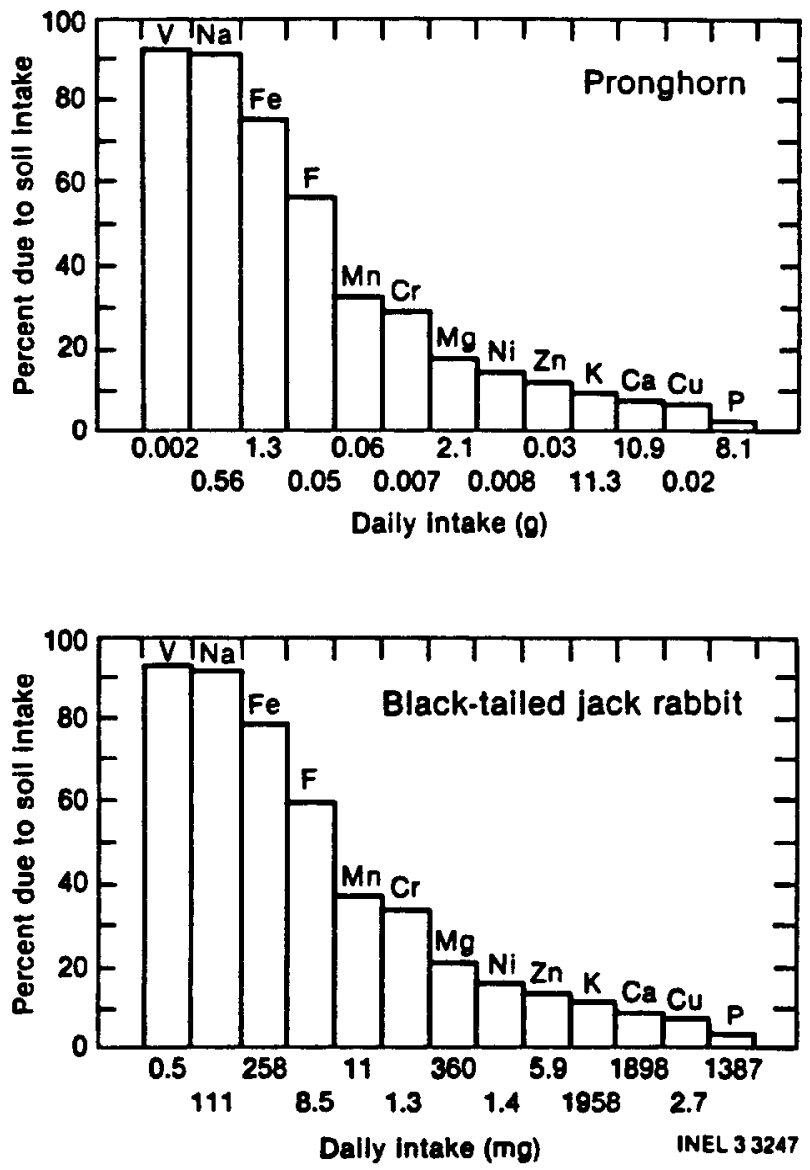

Fig. 2. Percentage of daily elemental intake of elements due to soil ingestion and estimated daily mass of each element ingested by pronghorns and black-1ailed jackrabbits on the Idaho National Engineering Laboratory.

Because soil comprised similar percentages of the total dry matter ingested by pronghorns (5.4\%) and jackrabbits (6.3\%), the overall percentage of the daily intake of elements resulting from soil ingestion was similar for these 2 species (Fig. 2). Soil ingestion resulted in a majority $(>50 \%)$ of the daily intake of the elements $\mathrm{Fe}$, $\mathrm{V}, \mathrm{Na}$, and $\mathrm{F}$ for pronghorns and jackrabbits. Greater than $30 \%$ of the intake of $\mathrm{Cr}$, and $\mathrm{Mn}$ was from soil ingestion. Vegetation ingestion resulted in greater than $90 \%$ of the daily intake of the elements $\mathrm{Ca}, \mathrm{Cu}$, and $\mathrm{P}$.

The total quantities of elements ingested via soil and forage intake were estimated by multiplying the mass of these media ingested by the respective mean concentrations of each element (Fig. 2). For pronghorn, the estimated daily $\mathrm{Na}, \mathrm{K}, \mathrm{Ca}, \mathrm{P}$, and $\mathrm{Mg}_{\mathrm{g}}$ intake via soil and vegetation ingestion was $0.56,11.3,10.9,8.1$, and $2.1 \mathrm{~g}$. Daily consumption of the trace elements $\mathrm{Cr}, \mathrm{V}$, and $\mathrm{Ni}$ was $0.007,0.002$, and $0.008 \mathrm{~g}$. Jackrabbit daily intake of the trace elements ranged from $0.0005 \mathrm{~g} \mathrm{~V}$ to $1.9 \mathrm{~g} \mathrm{~K}$ (Fig. 2).

\section{Discussion}

The methods we used to determine seasonal soil intake rates by pronghornsand black-tailed jackrabbits were based on the premise that high concentrations of titanium occur in soils, and titanium is not assimilated by vegetation or animal tissues. At our study area, titanium concentrations in soil exceeded previous reports, ranging from 3,760 to $5,260 \mathrm{ppm}$. Also, the titanium concentrations detected in sagebrush leaves and grass samples were higher than the reported level of $1 \mathrm{ppm}$ for vegetation (Healy 1968, Healy et al. 1970, Mayland et al. 1977). Higher titanium concentrations in vegetation may have been attributable to very fine soil particles remaining on vegetation after washing (Skinner 1982). A mean of $20 \mathrm{ppm}$ titanium in vegetation was used in the soil ingestion rate calculations to correct for titanium in forage; however, if we had used $1 \mathrm{ppm}$ titanium in vegetation, the mean soil intake rates would have increased only from 5 to $13 \%$ for pronghorns and from 4 to $10 \%$ for black-tailed jackrabbits.

Mean $(\bar{x} ; 95 \%$ confidence interval) daily soil intake rates for pronghorns and black-tailed jackrabbits were $48.7(45-52.7)$ and $9.7(9.0-10.6) \mathrm{g}$ soil/day. Soil comprised 5.4 and $6.3 \%$ of the total daily dry matter intake for pronghorns and jackrabbits. These percentages are greater than the 0.6 to $2.1 \%$ of the dry matter intake estimated for mule deer in northcentral Colorado (Arthur and Alldredge 1979) and greater than $2 \%$ of the dry matter intake estimated for cattle in New Zealand (Healy et al. 1970). Mayland et al. (1977) estimated that soil comprised $7 \%$ of dry matter intake for cattle feeding on Idaho grassland.

Monthly soil intake rates calculated in this study indicated 2 seasonal peaks in soil ingestion by pronghorns and jackrabbits. Mean soil intake rates during March through May increased 73\% over the previous 2 months for jackrabbits and $93 \%$ over the previous 3 months for pronghorns. Soil intake by jackrabbits was relatively low during June through August, but increased $76 \%$ to a second peak in September and October. An anomalous peak occurred in December 1980 when jackrabbit soil intake was 110 and $140 \%$ higher than in January and November 1981, respectively. Similar to those for jackrabbits, a second peak occurred during August and October when mean intake increased 130\% over June and July. Pronghorn soil intake returned to a relatively low level in November.

We cannot explain monthly trends in soil intake rates because direct observations of pronghorns and jackrabbits consuming soil were rare. One possible reason for lower soil intake rates during winter months was the existence of snow cover. Average monthly snow depth was low during the period when fecal samples were collected with $17.5,21.6,2.5$, and $2.5 \mathrm{~cm}$ snow in December 1980 and January, February, and March 1981. The months of peak snow depth were the same as the months when lower soil intake rates occurred for pronghorns. For jackrabbits, however, this was not true, since in December when the snow depth was $17.5 \mathrm{~cm}$ the highest soil intake rate of $8.4 \pm 3.5 \mathrm{~g} /$ day was obtained. For jackrabbits, it appears that decreases in soil intake rates were not associated with snow depths.

Tame mule deer (Odocoileus hemionus) feeding in northcentral Colorado had higher soil intake rates in spring than during other seasons, because they consumed soil attached to roots of new growth grasses and forbs (Arthur and Alldredge 1979). Similarly, we observed new growth of forbs in late April and May (J.E. Anderson, pers. commun.), during which time soil intake rates for jackrabbits and pronghorns were high. Examination of pronghorn fecal samples (R.J. Gates, unpubl. data) indicated that forbs comprised $41 \%$ of the May diet, whereas in the preceding 6 months forbs never comprised greater than $6 \%$ of the fecal fragments. Therefore, soil intake rates in March and April (months when sagebrush comprised greater than $90 \%$ of the diet) resulted from direct consumption of soil or attachment of soil to sagebrush leaves.

Soil ingestion by jackrabbits may have been related to the proportion of phlox (Phlox hoodii) and winterfat in the diet (R.J. Gates, unpubl. data). Ninety-nine jackrabbit fecal samples were analyzed for titanium concentrations and the occurrence of plant 
tissue fragments. Titanium concentration was correlated with percent of phlox and winterfat fragments in fecal samples $(r=0.91$, $\leq 0.01)$. During vegetation collections, we noted a large amount of soil attachment on the surface of phlox and winterfat. The low growth forms of winterfat and of phlox may have caused indirect soil intake when they were eaten.

Skipworth (1974) suggested that animals may consume soils as a source of trace elements when vegetation lacks these elements. The peaks in pronghorn and jackrabbit soil intake which we observed during March through May coincided with maximum salt lick use by white-tailed deer in southern Indiana that was necessitated by increased sodium requirements during the spring (Weeks and Kirkpatrick 1976). Obligatory intake of large amounts of potassium and water with succulent forage during spring may result in a negative sodium balance, which could be corrected by forage consumption, because plants contained low sodium concentrations (Weeks and Kirkpatrick 1976). Our soil samples contained high levels of $\mathrm{Na}$ and $\mathrm{K}$ compared to grass and sagebrush leaves (Table 2). The $\mathrm{Na}: \mathrm{K}$ ratio of soil was 0.47 while the same ratios were 0.0056 in grass and 0.0039 in sagebrush leaves. We observed spring and fall peaks in soil intake by pronghorns and jackrabbits, similar to peaks in Na-drive observed in fox squirrels and woodchucks by Weeks and Kirkpatrick (1978). Our results resemble the findings of Weeks and Kirkpatrick $(1976,1978)$ in that soil ingestion by pronghoms and jackrabbits could have offset a high dietary intake of $\mathbf{K}$, especially during spring and fall when vegetation resumes growth after dormancy. Excessive dietary $\mathrm{K}$ may interfere with otherwise efficient $\mathrm{Na}$-conserving mechanisms of herbivores. Approximately 92 and $93 \%$ of daily $\mathrm{Na}$ intake by pronghorns and jackrabbits was attributable to soil ingestion.

Regression analysis used in our study provided an estimate of the importance of soil ingestion in elemental intake by pronghorns and jackrabbits. For the elements $\mathrm{Fe}, \mathrm{V}, \mathrm{Na}$, and $\mathrm{F}$, greater than $50 \%$ of the estimated daily intake was attributed to soil ingestion. Data collected over the last 25 years indicates that in addition to $\mathrm{Fe}, \mathrm{F}$, and $\mathrm{V}$ are also essential nutrients for animals (Miller and Neathery 1977). Similarly, soil intake resulted in $10-50 \%$ of the daily intake of the elements $\mathrm{Cr}, \mathrm{Mg}, \mathrm{Mn}, \mathrm{Ni}$, and $\mathrm{Zn}$. The availability of the soil ingested elements for animal tissue assimilation is unknown. However, ingested soil is subject to a wide variety of digestive processes such as $\mathrm{pH}$ changes, bacterial breakdown, and complexing agents. Some microelements are absorbed into animal tissue directly from ingested soil (Healy et al. 1970). In addition to soil ingestion functioning as a major intake mechanism for trace elements, it is also likely an important pathway for intake of environmental contaminants such as radionuclides, herbicides, and insecticides (Healy 1973).

\section{Literature Cited}

Anderson, J.E., and R.D. Johmson. 1983. Impacts of jackrabbit herbivory on sagebrush steppe vegetation. In: Markham, O.D. ed. Idaho National Engineering Laboratory Radioecology and Ecology Programs 1983 Prog. Rep. Nat. Tech. Inf. Serv., Springfield, Va.

Arnold, J.F., and H.G. Reynolds. 1943. Droppings of Arizona and antelope jackrabbits and the "pellet census". J. Wildl. Manage. 7:322-327.

Arthur, W.J., and A.W. Alldredge. 1979. Soil ingestion by mule deer in northcentral Colorado. J. Range Manage. 32:67-71.

Duncan, D.B. 1955. Multiple range and multiple F tests. Biometrics 11:1-42.

Healy, W.B., 1968. Ingestion of soil by dairy cows. New Zealand J. Agr. Res. 11:487-499.

Healy, W.B. 1973. Nutritional aspects of soil ingestion by grazing animals. P. 567-588. In: Butler, G.W., and R.W. Bailey, eds. Chemistry and biochemistry of herbage. Vol. I, Academic Press, London.

Healy, W.B., W.J. MeCabe, and G.F. Wilson. 1970. Ingested soil as a source of microelements for grazing animals. New Zealand J. Agr. Res. 13:503-521.

Mayland, H.F., A.R. Florence, R.C. Rosenau, V.A. Lazar, and H.A. Turner. 1975. Soil ingestion by cattle on semiarid range as reflected by titanium analysis of foces. J. Range Manage. 28:448-452.

Mayland, H.F., G.E. Shewmaker, and R.C. Bull. 1977. Soil ingestion by cattle grazing crested wheatgrass. J. Range Manage. 30:264-265.

MeBride, R., N.R. French, A.H. Dahl, and J.E. Detmer. 1978. Vegetation types and surface soils of the Idaho National Engineering Laboratory Site. IDO-12084. Nat. Tech. Serv., Springfield, Va.

Miller, W.J., and M.W. Neathery. 1977. Newly recognized trace mineral elements and their role in animal nutrition. Bioscience 27:674-679.

Salter, R.E., and D.J. Pluth. 1980. Determinants of mineral lick utilization by feral horses. Northwest Sci. 54:109-118.

Severson, K., M. May, and W. Hepworth. 1968. Food preferences, carrying capacities and forage competition between antelope and domestic sheep in Wyoming's Red Desert. Sci. Monogr. 10. Agr. Exp. Sta. Univ. Wyoming, Laramie.

Skinner, D.J. 1982. ${ }^{226}$ Ra contamination of soil and foliage as a function of downwind distance from uranium mill tailings. M.S. Thesis, Colorado State Univ., Fort Collins.

Skipworth, J.P. 1974. Ingestion of grit by bighorn sheep. J. Wildl. Manage. 38:880-883.

Stoddart, L.C. 1983. Relative abundance of coyotes, lagomorphs and rodents in the Idaho National Engineering Laboratory. In: Markham, 0 . D., ed. Idaho National Engineering Laboratory Radioecology and Ecology Programs 1983 Prog. Rep. Nat. Tech. Inf. Serv., Springfield, Va.

Weeks, H.P., and C.M. Kirkpatrick. 1976. Adaptations of white-tailed deer to naturally occurring sodium deficiencies. J. Wildl. Manage. 40:610-625.

Welch, B.L., J.C. Pederson, and W.P. Clay. 1983. Ability of different rumen inocula to digest range forages. J. Wildl. Manage. 47:873-877. 